\title{
Debata nad środkami zabezpieczającymi w świetle obrad międzynarodowych kongresów penitencjarnych do II wojny światowej
}

W XIX wieku wprowadzono nowe formy obiegu naukowego. Wcześniej dyskusja nad zagadnieniami prawnymi ograniczała się do grona czytelników specjalistycznych publikacji i polemik. Najważniejszą z owych nowych form były debaty, które przybierały postać międzynarodowej wymiany myśli w bezpośredniej dyskusji. Łączyło się to z prawdziwym wysypem rozmaitych zjazdów, kongresów itp. ${ }^{1} \mathrm{Z}$ najbardziej znaczących należałoby wymienić Międzynarodowe Zjazdy Prawa Karnego, Kongresy Nieletnich, Kongresy Pupilarne (Opiekuńcze), jak również Międzynarodowe Kongresy Penitencjarne. To właśnie dorobek tych ostatnich będzie przedmiotem tego opracowania. Skąd taki wybór? Jest on podyktowany kilkoma względami.

Międzynarodowe Zjazdy Prawa Karnego koncentrowały się na węzłowych problemach prawa karnego materialnego, w szczególności generalnych zasadach odpowiedzialności karnej, zakresowi penalizacji i typizacji poszczególnych przestępstw i kwantyfikacji ewentualnej kary. Na tej bazie podejmowano zagadnienia bardziej szczegółowe².

Bardzo interesujący jest dorobek Kongresów Nieletnich, w których obradach poczesne miejsce zajmowali przedstawiciele Polski, z Walentym Miklaszewskim na czele. Rola tych konferencji była o tyle ważna, że ich głównym dążeniem było

\footnotetext{
${ }^{1}$ Malowniczo opisuje ten trend W. Spasowicz, Czwarty kongres więzienny międzynarodowy w Petersburgu w czerwcu 1890 r.,,Ateneum” 1890, t. III, z. 8, s. 340-341.

2 Por. W. Sokalski, Kongres prawa karnego w Palermo, „Głos Sądownictwa” 1933, nr 5, J. Śliwowski, IV Międzynarodowy Kongres Prawa Karnego (Paryż 25-31.VII.1937 r.), „Przegląd Więziennictwa Polskiego" 1937, nr 3.
} 
wyprowadzenie nieletnich z systemu więziennego i spod władzy praw karnych ${ }^{3}$. Ważnymi elementami debaty były także określenie wieku, po osiągnięciu którego człowiek powinien odpowiadać karnie ${ }^{4}$, rozwiązanie problemu „dzieci państwa” (nazywanego dziś sieroctwem społecznym) czy granic władzy rodzicielskiej i dopuszczalności karcenia na zasadzie „patria potestas”. Rozważania na te tematy były wypadkową problematyki prawnokarnej, prawa opiekuńczego i pedagogiki, której wskazania modelowały rozwiązania pozostałych. Warto zauważyć że, jak podkreślają historycy więziennictwa, również inspiracje dla nowożytnej polityki penitencjarnej zorientowanej na wychowawcze funkcje kary wywodziły się z podejścia wiążącego racje prawa karnego z możliwościami pedagogiki ${ }^{6}$.

Kongresy Pupilarne, które w polskiej literaturze tak prawniczej, jak i pedagogicznej miały słaby rezonans, zajmowały się, jak się wydaje, zagadnieniami polityki społecznej, ograniczając się głównie do dzieci i młodzieży zagrożonych demoralizacją ${ }^{7}$.

Wśród tych kongresów szczególne znaczenie miały Kongresy Penitencjarne, ponieważ były zorientowane na problematykę wykonania kary pozbawienia wolności i pierwsze faktycznie ograniczały się do tej tematyki. $Z$ czasem zaczęto pod obrady wprowadzać zagadnienia związane z etiologią przestępczości (włóczęgostwo, alkoholizm etc.), w ślad za tym, jak w doktrynach penologicznych, oriento-

${ }^{3}$ M. Korenfeld, Dzieci przed sądem. Sprawozdanie z kongresu odbytego w Paryżu w czerwcu roku bieżącego, „Gazeta Sądowa Warszawska” 1911, nr 47, s. 715 i n., W.P. Miklaszewski, Trzeci zjazd przedstawicieli zakładów poprawczych w Moskwie od 27 czerwca do 7 lipca 1890 r., „Gazeta Sądowa Warszawska" 1890, nr 40, s. 637.

${ }^{4}$ Podobne wątki pojawiały się także i na forum kongresów penitencjarnych, np. w Pradze (1930 r.), gdy celem optymalizacji postępowania z młodocianymi sprawcami proponowano powołanie specjalnych sądów dla przestępców w wieku 18-25 lat. Miały one, co ma w tym kontekście kluczowe znaczenie, rozpatrywać takie przypadki z przyjęciem priorytetu wychowania i opieki E. Holländer, X Międzynarodowy Kongres Karny i Penitencjarny w Pradze, „Czasopismo Sędziowskie" 1930, nr 11-12, s. 287-288.

5 W.P. Miklaszewski, VIII Zjazd przedstawicieli zakładów wychowawczo-poprawczych, „Gazeta Sądowa Warszawska" 1911, nr 48.

${ }^{6}$ Zob. J. Dukaczewski, Z historii instytucji i koncepcji resocjalizacyjnych $w$ Europie $i$ USA [w:] K. Pospiszyl (red.), Resocjalizacja nieletnich. Doświadczenia i koncepcje, Warszawa 1990, s. 16 i n. O roli J. Howarda w dobie kryzysu idei więzienia w Europie i próbach nadania mu nowej treści - J. Śliwowski, John Howard a współczesne kierunki polityki penitencjarnej, „Państwo i Prawo" 1978, nr 3, s. 71-74. Proces krystalizowania się poprawczej racjonalizacji kary zaprezentował jeszcze w XIX wieku H. Giegużyński - O karze w ogólności, „Przegląd Sądowy” 1871, t. XII, z. 1, s. 19 i n. Na temat trudności pogodzenia racji prawa i pedagogiki zob. Z. Żytomirski, Kilka słów o więziennictwie, „Na Posterunku” 1922, nr 20, s. 308.

${ }^{7} \mathrm{Na}$ temat relatywnie wczesnego dostrzeżenia konieczności otoczenia dzieci i młodzieży opieką w celu antycypowania przyszłej przestępczości zob. D. Raś, Rodziny ubogie i przestępczość od XVI do XX wieku. Warunki życia, badania psychologiczno-społeczne, dobroczynność $i$ wychowanie młodzieży, Kraków 2011, s. 10 i n. 
wano się na poprawcze cele kary ${ }^{8}$. W sposób naturalny zostały także rozwinięte na zagadnienia profilaktyki przedprzestępczej, zwanej „środkami uprzedzającymi”. Na tym etapie rozwoju prawa karnego, gdy teorie prawnokarne kształtowały się pod wpływem szkół antropologicznej i socjologicznej, naturalne było wprowadzenie do dyskusji problematyki modelowania wykonania kary pozbawienia wolności (wyroki nieoznaczone, warunkowe przedterminowe zwolnienie, warunkowe skazanie), a później także obocznych środków represji. Wśród tych ostatnich, należy przede wszystkim wymienić pozawięzienne instytucje adaptacyjne, takie jak domy pracy przymusowej, domy poprawy i przytułku (legitymizowanych racjami represyjnej profilaktyki społecznej), zakłady dla obłąkanych, przestępców „niepoczytalnych” oraz środki zabezpieczające dla niepoprawnych przestępców i alkoholików.

Kongresy Penitencjarne poza problematyką wykonania tak szerokiej gamy środków, podejmowały - jako problemy istotne dla ich efektywności - przygotowanie merytoryczne i zasady etyki zawodowej justycjariuszy ${ }^{10}$. Jak widać z powyższego, było to forum rozstrzygające zagadnienia problematyki, którą śmiało można by określić polityką kryminalną.

W związku z powyższym wydaje się zasadne przeanalizowanie, jaką pozycję zajmowały w tych debatach środki zabezpieczające, które po I wojnie światowej stały się równorzędnym segmentem polityki karnej i poza wyodrębnionymi już w prawie karnym kategoriami przestępców niepoczytalnych i niepoprawnych, obejmowano nimi sprawców uzależnionych (wtedy głównie od alkoholu). Retrospektywna analiza tych debat nie wyczerpuje się w aspekcie historycznym - problem środków zabezpieczających dla sprawców ze zmienionym stanem świadomości zyskał dużą rangę przy okazji niedawnej gruntownej nowelizacji Kodeksu

${ }^{8}$ J. Utrat-Milecki, Podstawy penologii. Teoria kary, Warszawa 2006, s. 117 i n.

9 Termin ten pojawia się chociażby jako określający sekcję obrad kongresów w Paryżu (1895 r.) i Budapeszcie (1905 r.); zob. odpowiednio A.M., Piąty zjazd (kongres) międzynarodowy więzienny (penitencjarny) w Paryżu, „Gazeta Sądowa Warszawska” 1895, nr 38-44, s. 665 i A. Moldenhawer, Pytania przyjęte do programatu VII-go kongresu penitencjarnego (więziennego) w Budapeszcie w 1905 roku, „Gazeta Sądowa Warszawska” 1904, nr 43, s. 686-687.

${ }^{10}$ I tak w Petersburgu (1890 r.) postulowano wyodrębnienie na uniwersytetach wszystkich państw studiów o wykonaniu kary i wymaganie od wyższego personelu penitencjarnego akademickiej wiedzy z zakresu historii i teorii penitencjarnej. Natomiast w Pradze (1930 r.) sformułowano oczekiwanie położenia nacisku w kształceniu więzienników na aspekty społeczno-pedagogiczne - J. Górny, Standardem w kadrę, „Forum Penitencjarne” 2000, nr 4, s. 14. Na temat rekomendacji w tym zakresie pierwszych kongresów, a także petersburskiego i praskiego zdawkowo J. Pyrcak, Kadra Stużby Więziennej [w:] A. Marek (red.), Księga Jubileuszowa Więziennictwa Polskiego1918-1988, Warszawa 1990, s. 247-248. W. Spasowicz, Czwarty kongres więzienny międzynarodowy $w$ Petersburgu..., s. 348. 
karnego w tym zakresie ${ }^{11}$. Warto, wydaje się, sięgnąc do czasu, w którym koncepcja środków zabezpieczających zaczynała się krystalizować, i spróbować odtworzyć, jakie temu przyświecały racje. Jest to tym bardziej zasadne, gdy wziąć pod uwagę daleko idącą krytykę środków zabezpieczających po II wojnie światowej $^{12} \mathrm{i}$ ich renesans siedemdziesiąt lat później, który współcześnie obserwujemy. Z punktu widzenia środków zabezpieczających nie można nie wspomnieć kongresów antropologii kryminalnej i kongresów obrony społecznej, które wprost wyrastały z takiego sposobu reagowania na przestępstwo. Kongresy te nie obradowały, rzecz jasna, w próżni, co więcej zdarzało się, że powierzano im jakiś problem do analizy aby w ten sposób przygotować grunt pod późniejszą uchwałę kongresu penitencjarnego. Niekiedy działało to i w drugą stronę, jednak wiodąca rola należała do kongresów penitencjarnych ${ }^{13}$.

Przechodząc już do samych Kongresów Penitencjarnych, wypada na wstępie zrobić kilka uwag. Istotne znaczenie miała formalna organizacja kongresów rekomendacje były przyjmowane w efekcie dyskusji najwybitniejszych reprezentantów nauki o więziennictwie $\mathrm{z}$ całego świata, jak również przedstawicieli praktyki i władz państwowych ${ }^{14}$. Znalezienie się w gronie uczestników miało znamię pewnej elitarności - jak pisał J. Serkowski: „tylko oficjalni delegaci państw, członkowie parlamentów i kół dyplomatycznych, wysłańcy towarzystw humanitarnych, profesorowie uniwersytetów, sędziowie, adwokaci, wyżsi kierownicy zakładów karnych i osoby specjalnie zaproszone (...) mogą być czynnymi członkami kongresu i głosować; nie ma więc mowy o tym, aby osobistości niekompetentne na ostateczne wyniki głosowania wpływały"15. Kongresy z założenia nastawione były na rozwiązywanie konkretnych problemów, o czym świadczy fakt, że ich dorobek miał postać rekomendacji kierowanych do państw. Przy czym należy zaznaczyć, że zalecano wprowadzanie ich do porządku prawnego i faktyczne stosowanie $\mathrm{z}$ uwzględnieniem lokalnej specyfiki danego kraju. Miały one zatem charakter ogólnych dyrektyw kierunkowych, $\mathrm{z}$ tego też m.in. powodu istotne było zaangażowanie w obrady urzędników państwowych.

Choć pierwsze z nich miały bardziej charakter konferencji, to jednak już w Brukseli (1847 r.) uradzono powołać stowarzyszenie więzienne, które w za-

${ }^{11}$ Ustawa z 20 lutego 2015 roku o zmianie ustawy Kodeks karny oraz niektórych innych ustaw (Dz.U. z 2015 r. poz. 396).

${ }^{12}$ A. Flatau-Kowalska, Środki zabezpieczające w prawie karnym, Warszawa 1956, s. 217 i n.

13 J. Górny, Rola międzynarodowych kongresów penitencjarnych w rozwoju teorii i praktyki wykonania kary, Warszawa 1980, s. 18-19.

${ }_{14}$ Dane liczbowe dotyczące liczby reprezentowanych państw, członków obrad, liczby referatów i publikacji pokongresowych przytacza J.Serkowski, Sprawozdanie z VII międzynarodowego kongresu w sprawach ustawodawstwa karnego $i$ więzien, odbytego w Budapeszcie $w$ dniach 3 do 9 września 1905, „Przegląd Prawa i Administracji” 1906, rok XXXI, s. 41.

15 Ibidem, s. 42. 
łożeniu miało zajmować się organizowaniem kongresów penitencjarnych ${ }^{16}$. Od kongresu londyńskiego (1872 r.) zaczęły im towarzyszyć elementy organizacyjne wprowadzające wyraźny atrybut instytucjonalizacji. Istotna była w tym zakresie rola utworzonej w 1877 roku Międzynarodowej Komisji Penitencjarnej, której powierzono zadanie m.in. ustalania miejsc i terminów kongresów, listy zaproszeń i dostarczania materiałów ich uczestnikom ${ }^{17}$. Natomiast kongresy międzywojenne odbywały się pod patronatem Ligi Narodów ${ }^{18}$. Z merytorycznego punktu widzenia najistotniejsza tu była zestandaryzowana procedura doboru problemówich proponowanie nie tyle przez poszczególnych uczestników, ile przez aparaty państwowe. Prace przygotowawcze, dyskusje, a także wypracowywane rezolucje były starannie udokumentowane i zestawiane z ówczesnym stanem wiedzy naukowej - z tym należy chyba przede wszystkim wiązać poważanie, jakim cieszyły się w środowiskach karnistów i penitencjarystów. W konsekwencji, nawet jeśli wypracowane postulaty nie były wdrażane, to stanowiły istotny punkt odniesienia przy ocenie stanu więziennictwa w poszczególnych państwach.

Jak pisał Aleksander Moldenhawer, idea kongresów więziennych zaczęła kiełkować w Stanach Zjednoczonych i miała wymiar lokalny - po prostu „urzędnicy przeróżnych więzień zjeżdżali się dla roztrząsania kwestyj, odnoszących się do tamtejszych zakładów"19. J. Górny, nawiązując do periodyzacji zaproponowanej jeszcze przez A. Moldenhawera, dzieli międzynarodowe kongresy penitencjarne na trzy chronologiczne sekwencje: obradujące w latach 1846-1870, następnie organizowane pomiędzy 1872 a 1935 rokiem i wreszcie na te zwołane już po II wojnie światowej ${ }^{20}$. Przyjmuje się, że pierwszy z kongresów obradował w dwóch sesjach - w 1846 roku we Frankfurcie nad Menem i w następnym roku w Brukseli (zarówno pierwsza jak i druga odsłona trwała zaledwie trzy dni ${ }^{21}$ ). Debaty te, w których zorganizowaniu istotną rolę odegrał ,słynny frankfurcki pisarz” Grzegorz Varrentrapp ${ }^{22}$ (charakter ,prywatnej inicjatywy” był zresztą typo-

16 J. Górny, Rola międzynarodowych kongresów..., s. 11.

17 Ibidem, s. 22-25.

18 Ibidem, s. 19.

19 A. Moldenhawer, O międzynarodowych zebraniach (kongresach) więziennych (penitencjarnych), „Gazeta Sądowa Warszawska” 1893, nr 14, s. 252.

20 J. Górny, Międzynarodowe kongresy penitencjarne. Milowe kroki w rozwoju myśli penitencjarnej, „Gazeta Penitencjarna” 1978, nr 2.

21 W. Piłat, Kongresy międzynarodowe karne i ich znaczenie, „Przewodnik Naukowy i Literacki” 1881, z. 9, s. 772-773.

22 A. Moldenhawer, O międzynarodowych zebraniach (kongresach) więziennych..., s. 252. Od Władysława Piłata dowiadujemy się, że był współwydawcą periodyku o tematyce penitencjarnej Jahrbücher der Gefäengnisskunde, sekretarzem obrad i wydawcą rezolucji kongresowych - Kongresy międzynarodowe karne..., s. 772. Natomiast Włodzimierz Spasowicz pisze, że G. Varrentrapp był lekarzem - Czwarty kongres więzienny międzynarodowy w Petersburgu..., s.341. 
wy dla pierwszych kongresów ${ }^{23}$ ) były skoncentrowane wokół oceny efektywności systemu celkowego (w szczególności w odmianie pensylwańskiej) i zasadności jego przeniesienia na grunt europejski ${ }^{24}$. Oprócz zagadnień stricte penitencjarnych podejmowano tam także bardziej ogólne wątki - społeczne, ekonomiczne czy dobroczynności ${ }^{25}$. Istnieją przesłanki wskazujące, że pierwszy kongres penitencjarny odbył się przy okazji zaplanowanego wcześniej kongresu prawników, historyków i filologów niemieckich, co oprócz walorów logistycznych determinowało także typ uczestników ${ }^{26}$.

W 1857 roku penitencjaryści ponownie zebrali się we Frankfurcie.

Kongres w Cincinnati (1870 r.) przeszedł do historii myśli penitencjarnej jako przełomowy dla sposobu myślenia o wymaganych kompetencjach zawodowych pracowników więziennictwa. O tym, że takie kompetencje są niezbędne, stanowiła przyjęta wówczas Deklaracja podstawowych zasad penitencjaryzmu amerykańskiego ${ }^{27}$. Było to także gremium, które opowiedziało się za szerokim stosowaniem wyroków nieoznaczonych. Miały one umożliwić reagowanie na zmiany w społecznym nastawieniu skazanego. Wariant ten wprowadzono w życie niedługo potem w więzieniu w Elmirze, a wzór ten powielano także w innych niż nowojorski stanach USA ${ }^{28}$.

Wydaje się jednak, że brak zaplecza instytucjonalnego i radykalizm niektórych postulatów nie pozwoliły rezolucjom wczesnych kongresów odegrać istotniejszej roli sprawczej ${ }^{29}$.

Kongresy drugiej serii obradowały już w kontekście rozwijającej się dyskusji pomiędzy klasyczną szkołą prawa karnego a rywalizującymi z nią nurtami pozytywistycznymi: antropologiczno-biologicznym i socjologicznym ${ }^{30}$. Gdy chodzi o system wykonania kary pozbawienia wolności, rekomendowały one sukcesywnie rozwiązania coraz bardziej progresywne kosztem umiarkowanych wariantów izolacji celkowej ${ }^{31}$.

${ }^{23}$ A. Moldenhawer, Kongresy więzienne międzynarodowe, „Przegląd Literacki” 1887/1888, t. VII, nr 52.

${ }^{24} \mathrm{~J}$. Górny, Międzynarodowe kongresy penitencjarne. Milowe kroki....

${ }^{25}$ A. Moldenhawer, O międzynarodowych zebraniach (kongresach) więziennych ..., s. 253.

${ }^{26}$ J. Górny, Rola międzynarodowych kongresów..., s. 9.

${ }^{27}$ K. Bedyński, Organizacja doskonalenia zawodowego funkcjonariuszy więziennictwa [w:] A. Marek (red.), Księga jubileuszowa więziennictwa polskiego 1918-1988, Wydawnictwo Prawnicze, Warszawa 1990, s. 264.

${ }^{28}$ E. Neymark, System wyroków nieokreślonych, „Gazeta Sądowa Warszawska” 1926, nr 32.

${ }_{29}$ M. Korenfeld, Międzynarodowe kongresy penitencjarne i przyszby kongres $w$ Petersburgu, „Gazeta Sądowa Warszawska” 1888, nr 32, s. 553.

${ }^{30}$ J. Górny, Międzynarodowe kongresy penitencjarne. Druga seria. Nowe idee, „Gazeta Penitencjarna" 1978, nr 4.

31 J. Górny, Problematyka penitencjarna na międzynarodowych kongresach i sympozjach, „Przegląd Penitencjarny i Kryminologiczny” 1983, nr 3, s. 12. 
Zwołany z inicjatywy władz USA ${ }^{32}$, zorganizowany jednak na Starym Kontynencie, kongres londyński (1872 r.) rozpoczął sekwencję kongresów urzędowych, w których to „rządy, współ z uczonymi, czynny biorą udział, strzegąc się wzajemnie od zatonięcia bądź w stojącej wodzie rutyny, bądź w rozlewających się falach abstrakcyjnych spekulacyi”, jak to malowniczo określił M. Korenfeld ${ }^{33}$. Naczelną dewizą uczestników tej konferencji było dowartościowanie prewencji kosztem represji ${ }^{34}$. Obrady poprzedziła peregrynacja po Europie wysłannika Ulyssesa Granta, osiemnastego prezydenta USA. Wysłannik ten występuje w literaturze jako dr Vines (zm. 10.12.1879 r.), a jego misja miała na celu m.in. zapewnienie zgromadzeniu odpowiedniej frekwencji ${ }^{35}$.

Obrady w Sztokholmie (1878 r.), pod patronatem króla Oskara II $^{36}$, dotyczyły m.in. zagadnienia sprawców niepoprawnych. Zalecono stosowanie wobec nich systemu umoralniającego ${ }^{37}$. J. Śliwowski mówił o nim jako o ,pierwszym z kongresów”, nie precyzując niestety jakie względy przesądzały jego zdaniem o pominięciu poprzednich ${ }^{38}$.

Obrady w Rzymie planowano pierwotnie odbyć w roku 1884, jednak z uwagi na epidemię cholery przełożono je na rok następny ${ }^{39}$. Nie bez znaczenia był fakt, że w tym samym czasie obradował w Rzymie kongres antropologii kryminalnej, a znaczna część dyskutantów brała udział tak w jednej, jak i drugiej imprezie $^{40}$.

Kongres petersburski (1890 r.) zbiegł się z setną rocznicą śmierci Johna Howarda $^{41}$. W programie znaleźć można było m.in. problem ,jak może być przedstawione pijaństwo w prawodawstwie karnem?" - jako samoistne przestępstwo czy też jako okoliczność łagodząca, obciążająca, ew. wyłączająca odpowiedzialność karnąa $^{42}$. Ujawniły się na nim silnie poglądy wyrastające z nurtu socjologicznego, jak chociażby akcentowanie znaczenia rozwiązań profilaktycznych w ograni-

${ }^{32}$ M. Korenfeld, Międzynarodowe kongresy penitencjarne i przyszty kongres..., s. 554.

33 Ibidem, s. 553.

${ }^{34}$ Ibidem, s. 554.

${ }^{35}$ W. Piłat, Kongresy międzynarodowe karne..., s. 774.

${ }^{36}$ Ibidem, s. 777.

37 M. Sztokman Zakłady dla przestępców niepoprawnych, „Przegląd Więziennictwa Polskiego" 1934, nr 9, s. 9.

${ }^{38}$ XI Kongres Karny i Penitencjarny w Berlinie (wywiad Jerzego Szpera z Jerzym W. Śliwowskim), „Współczesna Myśl Prawnicza” 1935, nr 1, s. 24.

39 A. Moldenhawer, O międzynarodowych zebraniach (kongresach) więziennych ..., s. 253.

40 J. Górny, Problematyka penitencjarna ..., s. 19.

${ }^{41}$ M. Spolski, Międzynarodowy Kongres Penitencjarny w Petersburgu, „Prawnik” 1888, nr 19-20.

${ }^{42}$ M. Korenfeld, Międzynarodowe kongresy penitencjarne i przyszły kongres $w$ Petersburgu, „Gazeta Sądowa Warszawska” 1888, nr 35, s. 602. 
czaniu przestępczości nieletnich, której obradujący poświęcili najwięcej czasu ${ }^{43}$. Natomiast przy okazji dyskusji na temat problemu występków „,pijackich”, rozważano możliwość zastosowania przymusowego odwyku (przy założeniu jednak, że dopiero stwarzanie niebezpieczeństwa dla otoczenia lub bycie „ciężarem dla dobroczynności” może być podstawą interwencji). Jako istotną sprawę wymieniono zasadność surowszego karania szynkarzy za sprzedawanie alkoholu ludziom wyraźnie pijanym ${ }^{44}$. Ponadto przyjęto wówczas, że „ci, których uważa się za niepoprawnych, są właściwie tylko niepoprawieni”, a recydywa nie dowodzi niepoprawności przestępców. Argumentowano przy tym, że pedagogika więzienna wciąż się rozwija, więc nowe metody mogą przynieść lepsze efekty, a poza tym społeczeństwo nie dba dostatecznie o los wychodzących na wolność - w tym sensie jest więc samo sobie winne ${ }^{45}$.

W Paryżu (1895 r.) obradowano pod wiele obiecującym hasłem „Cześć miłosierdziu i nauce" ${ }^{46}$. Poczesne miejsce w programie zajmowała problematyka alkoholizmu jako stymulatora patologii społecznej ${ }^{47}$. Samo zaś zjawisko nadużywania napojów wyskokowych oceniono jako zdecydowanie zbyt dynamicznie się rozprzestrzeniające ${ }^{48}$. Pojawiające się na tym forum postulaty prohibicyjne nie zyskały jednak szerszej aprobaty ${ }^{49}$. W związku z tym w programie obrad znalazło się zagadnienie efektywności prewencyjnej prowadzenia „przytułków dla pijaków"50. Kongres wyraził życzenie, aby doszło do synergii wysiłków władz publicznych i prywatnych stowarzyszeń na polu działań profilaktycznych (m.in. ograniczenie dostępności alkoholu przy jednoczesnym obniżeniu cen trunków mniej toksycznych, zakładanie towarzystw wstrzemięźliwości) i terapeutycznych (tworzenie przytułków dla alkoholików, w których byliby oni wdrażani do pracy). Krajowe przepisy powinny, zdaniem obradujących, określić szczegółowe zasady traktowania osób umieszczonych w tych przytułkach, stosownie do tego, czy zgłosiły się dobrowolnie, ich pijaństwo stało się zagrożeniem dla nich samych oraz otoczenia, czy też są już skazywani jako „recydywista pijak”" nież kongres, na który po raz pierwszy „po 10 latach cichej pracy” wkroczyła antropometria - zalecono międzynarodowe ujednolicenie praktyki w tym zakresie ${ }^{52}$.

43 J. Górny, Międzynarodowe kongresy penitencjarne. W kręgu idei Howarda,,Gazeta Penitencjarna" 1978, nr 8.

${ }^{44}$ W. Spasowicz, Czwarty kongres więzienny międzynarodowy w Petersburgu ..., s. 348.

${ }^{45}$ M. Sztokman, Zakłady dla przestęców niepoprawnych ..., s. 10.

${ }^{46}$ A.M., Piąty zjazd (kongres) międzynarodowy więzienny (penitencjarny) w Paryżu..., s. 595.

${ }^{47}$ Ibidem, s. 595.

48 Ibidem, s. 674-675.

49 Ibidem, s. 675.

${ }^{50}$ Ibidem, s. 674.

${ }^{51}$ Ibidem, s. 675-676.

52 Ibidem, s. 648-649. 
W debacie mierzono się m.in. z pytaniem, w jaki sposób należy traktować czas, który skazany dotknięty „,ierpieniem umysłowym” już w trakcie odbywania kary, spędził w specjalistycznej placówce - czy właściwym jest „odliczanie” mu tego czasu od wymierzonej kary? Przeważyła opcja, że nie. Ponadto sformułowano pogląd, że jeśli przepisy krajowe dopuszczają ,,redukcję czasu zamknięcia oznaczonego przez wyrok pod warunkiem, że kara cierpianą będzie w celce - to kongres jest zdania, iż skazany obłąkany winien korzystać z tego dobrodziejstwa, nawet i wówczas, choćby podczas obłąkania przeniesionym został do wspólności" ${ }^{53}$. Do rozpatrzenia na następnym kongresie odłożono problem skonstruowania systemu stałej kontroli kondycji psychicznej uwięzionych oraz to, jak leczyć „obłąkanych” więźniów, aby „wymagania obchodzenia się z nimi mogły zgodzić się z represją" ${ }^{4}$. Węzłowe było jednak trzecie pytanie sekcji: „środki uprzedzające". Sprowadzało się ono do tego, jak chronić społeczeństwo przed sprawcami niepoczytalnymi i tymi, których poczytalność była tempore criminis zmniejszona ${ }^{55}$. Poglądy, które się przy tej okazji ujawniły były rozmaite: proponowano stworzyć dla takich sprawców zakłady łączące cechy szpitala i więzienia, specjalne przytułki, w których można by ich obserwować i badać, prezentowano także stanowisko, że właściwym miejscem są zwykłe domy dla obłąkanych, że należy wydzielić na potrzeby takich pacjentów specjalne oddziały w tychże. Pojawił się też problem wszechwładzy lekarza przy decydowaniu o wolności takiego sprawcy i iluzoryczność kontroli sądowej nad jego rozstrzygnięciami ${ }^{56}$. Dyskutantom udało się sformułować dezyderat, zgodnie z którym miejscem adekwatnym dla sprawców niepoczytalnych tudzież o ograniczonej poczytalności w czasie czynu są zakłady lub oddziały specjalne, jednakże o odzyskaniu przez takiego człowieka wolności powinny decydować władze trojakiego rodzaju: sądowa, administracyjna i medyczna $^{57}$. O rozmachu tego zebrania świadczyć może fakt, że pojawili się uczestnicy z tak odległych krajów, jak Nikaragua ${ }^{58}$.

Na kongresie brukselskim (1900 r.), ostatnim na którym zwolennicy systemu celkowego zdołali przeforsować swoje poglądy ${ }^{59}$, znajdujemy już konkretne zalecenia, odnośnie reżimów zakładów zabezpieczających ${ }^{60}$. Przewidziano wobec niepoprawnych surowszy rygor polegający m.in. na ograniczeniu nieuzasadnio-

${ }^{53}$ Ibidem, s. 659-661.

54 Ibidem, s. 661.

55 Ibidem, s. 665.

${ }^{56}$ Ibidem, s. 665-666.

${ }^{57}$ Ibidem, s. 666.

${ }^{58}$ Ibidem, s. 701.

59 J. Górny, Problematyka penitencjarna ..., s. 12.

${ }^{60}$ S. Czerwiński, Walka z przestępcami niepoprawnymi w świetle przepisów Kodeksu karnego i rozporządzenia Ministra Sprawiedliwości z dnia 15 stycznia 1934 (Dz. Ust. poz. 38), „Przegląd Więziennictwa Polskiego" 1935, nr 9. 
nych potrzeb (których imperatyw zaspokojenia bywa nierzadko impulsem dla przestępstwa), ograniczenie racji żywnościowych do wymiaru koniecznego dla podtrzymania sił fizycznych i zdrowia, ograniczenie możliwości kontaktu z własnym środowiskiem (najczęściej demoralizującym) z wolności czy też wdrożenie do pracy bardziej niż przeciętna ciężkiej (zakładano, że na wolności, aby uczciwie zarobić, człowiek taki będzie najpewniej zmuszony przyjąć każdą pracę) ${ }^{61}$. Pomimo postawienia problemu postępowania ze skazanymi alkoholikami (i głosów w dyskusji, które w alarmistycznym tonie diagnozowały destrukcyjny wpływ alkoholu na życie społeczne ${ }^{62}$ ), nie doszło do wypracowania w tym zakresie stanowiska, które byłoby ujęte w oficjalnych rezolucjach ${ }^{63}$. Skonstatowano bezsilność jeśli idzie o precyzyjne określenie wpływu pijaństwa na przestępczość. Postulowano jednak usunięcie wina $\mathrm{z}$ więzień, surowszy rygor dla uwięzionych alkoholików i propagandę antyalkoholową. Nie zabrakło też wyrażonej półżartem nadziei, że ludzkość doczeka się „serum antialkoholicznego" ${ }^{44}$. Rekomendowano włączenie tego zagadnienia do agendy kolejnego kongresu, konstatując jego złożoność ${ }^{65}$. Stwierdzono, że w przypadku leczenia sprawców chorych na umyśle, i w związku z tym nieodpowiedzialnych, wręcz konieczne jest odstąpienie od określania terminu zwolnienia ${ }^{66}$. Rozważano, czy istnieją kategorie przestępców wobec których zasadne byłoby zastosowanie wyroków bezterminowych i w jaki sposób należałoby to uregulować ${ }^{67}$. Podstawą dyskusji było opracowanie dotyczące stosowania wyroków bezterminowych w USA. Sprawozdawca, Izydor Maus, nie ukrywał swego krytycznego stosunku do tego rozwiązania - ,żadna zgoła idea leczenia nie da się pogodzić z pojęciem kary. Kara ma zawsze zakres, oznaczony jasno przez ważność winy: nie ma kary nieokreślonej" ${ }^{18}$. Referent określił modus operandi polegający na trzymaniu człowieka dopóty, dopóki nie przekształci się w pożądany sposób jego osobowości, jako „wręcz inkwizycyjne" ${ }^{\text {69 }}$. Zwracał ponadto uwagę na problem selekcjonowania osób, które miałyby śledzić ową przemianę

${ }^{61}$ Ibidem, s. 5.

${ }^{62}$ A. Moldenhawer, Kongres międzynarodowy więzienny w Brukselli w r. 1900, „Gazeta Sądowa Warszawska" 1901, nr 42-47, s. 603. Owacją przyjęto wystąpienie, w którym padło twierdzenie, iż kongresy penitencjarne powinny mierzyć się z problemem alkoholizmu „aż do chwili zamknięcia ostatniego z szynków, w których truciciele fabrykują napoje wyskokowe" - ibidem, s. 735.

${ }^{63} \mathrm{~J}$. Górny, Międzynarodowe kongresy penitencjarne. Największa aberracja XIX wieku,,,Gazeta Penitencjarna" 1978, nr 13.

${ }^{64}$ A. Moldenhawer, Kongres międzynarodowy więzienny w Brukselli..., s. 602.

${ }^{65}$ A. Moldenhawer, Pytania przyjęte do programatu VII-go kongresu penitencjarnego (więziennego) w Budapeszcie w 1905 roku, „Gazeta Sądowa Warszawska” 1904, nr 45, s. 719.

${ }^{66}$ E. Neymark System wyroków....

${ }^{67}$ A. Moldenhawer, Kongres międzynarodowy więzienny w Brukselli..., s. 543.

${ }^{68}$ Ibidem.

${ }^{69}$ Ibidem, s. 544. 
i na niebezpieczeństwo zdominowania przez tak maksymalistycznie pojmowany cel poprawczy innych aspektów kary, takich jak ,zadośćuczynienie, przykład i uprzedzenie przestępstwa" ${ }^{\text {"70 }}$. Najmocniej poparł I. Mausa profesor z Bolonii, Ugo Conti Sinibaldi (1864-1942) ${ }^{71}$. Zwolennicy wyroków nieoznaczonych, według relacji A. Moldenhawera, argumentowali, że w przypadku poprawy moralnej, o jaką w tej sytuacji chodzi, potrzeba ludzi gotowych przyjąć na siebie taką odpowiedzialność, a ponadto muszą zostać uwolnieni z biurokratycznego gorsetu. Twierdzili również, że nieoznaczony wyrok nie równa się wyrokowi nieskończonemu, proponując warunkowe uwolnienie po odbyciu minimum kary, na drugim biegunie widzieliby ,pięć czy siedem lat, jak w niektórych stanach Ameryki Północnej ${ }^{72}$. Po dalszej dyskusji, sekcja przyjęła większością głosów propozycję przewodniczącego w brzmieniu:

Dla zastosowania wyroków bezterminowych trzeba rozróżniać: kary w ścisłym znaczeniu, środki wychowawcze, opieki lub bezpieczeństwa i leczenie przestępców patologicznych. a) Co do kar właściwych systemat wyroków bezterminowych jest niedopuszczalnym. Można by go korzystniej zastąpić uwolnieniem warunkowym, skombinowanym z postępowym przedłużaniem kar dla recydywistów. b) Co się tyczy środków wychowania, protekcji lub bezpieczeństwa, to systemat wyroków bezterminowych mógłby być chyba dopuszczonym z ograniczeniami, które jednak pociągnęłyby zaniechanie samego systematu. Byłoby zatem prościej, logiczniej i praktyczniej trzymać się systematu kar długoterminowych, z dodaniem warunkowego uwolnienia. c) Natomiast nieoznaczenie zakresu leczenia winno być wprowadzone względem przestępców nieodpowiedzialnych, dotkniętych chorobą umysłową. Środki jednak przedsiębrane względem nich nie mają wcale charakteru karnego ${ }^{73}$.

W dyskusji nad programowymi założeniami systemów izolacyjnych ścierały się dwie główne racje: ochrony społeczeństwa i osiągnięcia poprawy moralnej uwięzionych. Najbardziej kontrowersyjne okazały się być sprawy związane z rolą lekarza w więzieniu i postępowaniem z recydywistami ${ }^{74}$. Krytycznie odnosząc się do przebiegu kongresu, A. Moldenhawer zwracał uwagę na marginalizację prominentnych przedstawicieli nauki (chociażby F. Liszta, R. Garofalo, E. Ferriego czy C. Stoosa) na rzecz głosu urzędniczego ${ }^{75}$.

Konferencje w Budapeszcie (1905 r.) i Waszyngtonie (1910 r.) łączył nie tylko stosunkowo krótki odstęp czasu pomiędzy obradami, lecz także ich zakres tema-

${ }^{70}$ Ibidem.

${ }^{71}$ Zob. http://www.treccani.it/enciclopedia/ugo-conti-sinibaldi_(Dizionario-Biografico) [dostęp: 25.08.2017].

72 A. Moldenhawer, Kongres międzynarodowy więzienny w Brukselli..., s. 544-545.

73 Ibidem, s. 546.

${ }^{74}$ A. Moldenhawer, Kongres międzynarodowy więzienny w Brukselli..., s. 557.

75 Ibidem, s. 748. 
tyczny. W konkluzjach obydwu mowa była o konieczności kategoryzacji zakładów karnych, w szczególności tych przeznaczonych dla sprawców o ograniczonej poczytalności i uzależnionych od alkoholu. W ślad za tym szło rekomendowanie badań osobopoznawczych. Przyjmuje się, że to właśnie kongres budapesztański dał początek ukonstytuowaniu kluczowej dla penitencjarystyki zasady indywidualizacji ${ }^{76}$. Program kongresu został podzielony na cztery sekcje, trzecia w kolejności miała się zajmować „środkami uprzedzającymi”"77. Jednak już w sekcji drugiej, poświęconej kwestiom ściśle penitencjarnym, pojawiło się zagadnienie: czy konieczne jest tworzenie specjalnych zakładów de détention dla sprawców o ograniczonej poczytalności (w kwestii zasadności wyodrębniania takich sprawców na etapie wykonawczym, zdania miały być wśród ówczesnych psychiatrów podzielone) i „zadawnionych pijaków” (którzy, według słów A. Moldenhawera, stanowili „nieustanne niebezpieczeństwo dla legalnego porządku”" ${ }^{\text {"78 }}$. Konsekwencją tak postawionego pytania miało być rozważenie, według jakich zasad takie instytucje powinny być urządzone ${ }^{79}$. Skonstatowano, że reżim powinien być w takich zakładach surowszy w porównaniu z placówkami dla obłąkanych, z zastrzeżeniem, że „zakładów tych nie należy nigdy w ten sposób powiększać, aby miały przybrać

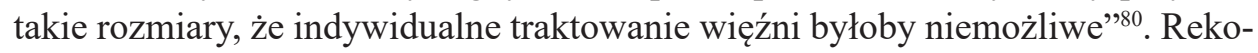
mendowano zatrudnianie takich skazanych na roli i „w rękodziełach”, systematyczne umoralnianie i leczenie „w miarę potrzeby" ${ }^{\prime 1}$. Jeśli chodzi o problematykę antyalkoholową, pojawił się postulat, aby krajowe ustawodawstwa dopuszczały możliwość dłuższego pobytu w „schronisku dla uleczalnych alkoholików” zamiast nominalnie wymierzonej kary pozbawienia wolności ${ }^{82}$. Z kolei w konkluzji obrad waszyngtońskich stwierdzono, że wyroki nieoznaczone powinno się stosować wobec sprawców o ,anormalnym rozwoju moralności lub umysłu”83. Przed tamtejszymi obradami postawiono zadanie określenia kategorii sprawców, którym należałoby aplikować wyroki nieoznaczone, jak również wypowiedzenia się

${ }^{76}$ J. Górny, Międzynarodowe kongresy penitencjarne. Klasyfikacja podstawa resocjalizacji, „Gazeta Penitencjarna” 1978, nr 19.

77 A. Moldenhawer, Pytania przyjęte do programatu VII-go kongresu penitencjarnego (więziennego) w Budapeszcie w 1905 roku, „Gazeta Sądowa Warszawska” 1904, nr 43, s. 686-687. Warto jednak zaznaczyć, że w sekcji tej podejmowano wiele różnych zagadnień, w tym problematykę zwalczania tuberkulozy w placówkach penitencjarnych.

${ }^{78}$ A. Moldenhawer, Pytania przyjęte do programatu VII-go kongresu penitencjarnego (więziennego) w Budapeszcie w 1905 roku, „Gazeta Sądowa Warszawska” 1904, nr 45, s. 719.

${ }^{79}$ Ibidem.

${ }^{80}$ J. Serkowski, Sprawozdanie z VII międzynarodowego kongresu w sprawach ustawodawstwa karnego i więzień, odbytego w Budapeszcie..., s. 57.

${ }^{81}$ Ibidem.

82 Ibidem, s. 59.

${ }^{83}$ E. Neymark, System wyroków.... 
w przedmiocie zasad uwalniania takich ludzi. W artykule N. Likierta, relacjonującym obrady waszyngtońskie, pojawia się wątek „specjalnej instancji sądowej”, której być może należałoby to zadanie powierzyćc ${ }^{84}$. Od razu jednak zastrzegano, że wyroków takich być może nie uda się pogodzić z ,zasadniczymi podstawami prawodawstwa karnego" i miano wówczas rozważyć, jakie inne ograniczenia wolności można w takich przypadkach dołączyć do zasadniczej kary ${ }^{85}$. Przed sekcją trzecią (,środki prewencyjne”) postawiono m.in. pytanie o to, czy pozytywnie należy ocenić długotrwałe (pod tym pojęciem rozumiano okres 2-3 lat) izolowanie przestępców-alkoholików, jak również w jaki sposób wzbogacić w takich przypadkach standardowe warunki odbywania kary, komponentem leczniczym ${ }^{86}$.

Kongres londyński planowany był na rok 1915, jednak plany te pokrzyżowała „wielka wojna"87. Faktycznie odbył się 10 lat później. Rekomendowano na nim badania kryminalno-antropologiczne jako konieczne dla projektowania polityki penitencjarnej, której celem jest, mówiąc dzisiejszym językiem, społeczna readaptacja przestępców ${ }^{88}$. Przyjęta tam jednomyślnie uchwała stanowiła m.in., że „niezbędnym jest, by wszyscy więźniowie, zarówno śledczy jak i skazani, byli poddawani badaniu fizycznemu i psychicznemu przez lekarzy specjalnie kwalifikowanych i by odpowiednie urządzenia zainstalowane zostały w zakładach (...) Tego rodzaju system badań przyczyni się do określenia biologicznych i społecznych przyczyn przestępczości i do ustalania właściwego traktowania każdego

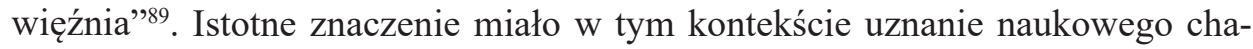
rakteru nurtu zapoczątkowanego przez Ludwika Vervaecka (który był zresztą, obok m.in. Enrico Ferriego, obecny na kongresie ${ }^{90}$ ) a nazywanego w ówczesnej literaturze „badaniami biologiczno-kryminalnymi”. Z punktu widzenia praktyki penitencjarnej istotne było to, że miały one stać się podstawą klasyfikacji podsądnych pozbawionych wolności ${ }^{91}$. Krytykując koncepcję wyroków nieoznaczonych (w szczególności karniści angielscy przeciwstawili się w tym zakresie koncepcji

${ }^{84}$ N. Likiert, Kongres międzynarodowy więzienny, „Gazeta Sądowa Warszawska” 1910, nr 28, s. 435.

${ }^{85}$ Ibidem.

${ }^{86}$ Ibidem, s. 437.

${ }^{87}$ IX Międzynarodowy Kongres Penitencjarny w Londynie (na podstawie relacji i materiałów udostępnionych przez Franciszka Głowackiego, dyrektora Departamentu Karnego Ministerstwa Sprawiedliwości), „Przegląd Więziennictwa Polskiego” 1925, nr 5, s.1.

${ }^{88}$ L. Radzinowicz, Drogi więziennictwa polskiego. Niezbędność myśli psychiatrycznej i pedagogicznej, „Gazeta Sądowa Warszawska” 1932, nr 52, s. 765 i n.

${ }^{89}$ L. Radzinowicz, Podstawy nauki o więziennictwie, Gebethner i Wolff, Warszawa 1933, s. 270 .

90 J. Górski, Rozpoznawanie osobowości skazanych [w:] A. Marek (red.), Księga jubileuszowa więziennictwa polskiego 1918-1988, Wydawnictwo Prawnicze, Warszawa 1990, s. 335-336.

${ }^{91}$ L. Radzinowicz, Współczesna ewolucja antropologii kryminalnej, Warszawa 1934. 
E. Ferriego ${ }^{92}$ ), postulowano jednakże rozwijanie prewencyjnych środków karnych i ochronnych środków zabezpieczających ${ }^{93}$. Przed obradującymi postawiono problem: „,czy jest możliwe i w jakim zakresie stosowanie wyroków nieokreślonych $\mathrm{w}$ walce $\mathrm{z}$ recydywą, dotyczącą nie tylko ciężkich zbrodni, lecz również wszelkich innych przestępstw". Decydenci podjęli jednak kompromisową wobec zarysowanej powyżej różnicy stanowisk rezolucję, w której stwierdzili jedynie, że wyroki nieoznaczone są najskuteczniejsze z punktu widzenia obrony społeczeństwa przed przestępczością. Jednak nie sformułowano żadnych bliższych zaleceń dla ustawodawstw krajowych w tym względzie, przyjmując minimalistyczną formułę, że zasady stosowania przedterminowego zwolnienia winny być dostosowane do „warunków społecznych każdego państwa" ${ }^{44}$. Stwierdzono natomiast, że ustawa karna powinna dać sędziemu szeroki wachlarz opcji, w tym prewencyjnych i ochronnych środków zabezpieczających, i nie ograniczać zbytnio jego dyskrecjonalnej władzy. W ślad za tym powinno jednak podążać wszechstronne kształcenie kandydatów na sędziów - w tym kontekście wymieniono psychologię i socjologię kryminalną, medycynę, psychiatrię sądową oraz penologię ${ }^{95}$. Korespondował z tym postulat poświęcenia się tak wykształconego prawnika tylko sprawom karnym ${ }^{96}$. Oprócz tego zaznaczono znaczenie szerokiego zdiagnozowania sytuacji życiowej i kondycji psychofizycznej podsądnego, zastrzegając, że w razie takiej potrzeby sąd powinien dysponować uprawnieniem do poddania takiej osoby badaniu przez specjalistów - tak medyków, jak i psychologów ${ }^{97}$. Skonstatowano także, że z punktu widzenia obrony społecznej jest pożądane funkcjonowanie „systemu specjalnego zamknięcia prewencyjnego”, zaznaczając przy tym, że reżim takiego uwięzienia powinien być łagodniejszy w porównaniu z tym dla więźniów karnych. Zamknięcie to miałoby być stosowane na czas nieokreślony, z możliwością warunkowego zwolnienia ${ }^{98}$. Odpowiadając na zagadnienie traktowania dorosłych osób anormalnych „ujawniających usposobienie niebez-

92 W. Sokalski, IX Międzynarodowy Kongres Penitencjarny. Londyn od 3 do 10 sierpnia 1925 roku, „Przegląd Więziennictwa Polskiego” 1926, nr 6, s. 2.

93 J. Górny, Międzynarodowe kongresy penitencjarne. Z udziałem Polski,„Gazeta Penitencjarna" 1978, nr 23.

${ }^{94}$ IX Międzynarodowy Kongres Penitencjarny w Londynie..., s. 3.

95 Ibidem. W debacie prawniczej w Polsce koncepcja ta została w sposób kompleksowy zaprezentowana przez Jerzego Śliwowskiego. Postulował on poszerzenie wykształcenia sędziów o przynajmniej elementarną wiedzę z zakresu medycyny. Pójście tą drogą umożliwiłoby z czasem wykształcenie specjalisty nowego typu: sędziego-lekarza, który dysponując wiedzą z zakresu psychologii, anatomii, fizjologii, psychiatrii, neurologii i antropologii mógłby realnie odgrywać rolę „najwyższego biegłego” - Lekarz-sędzia czy sędzia-lekarz, „Czasopismo Sądowo-Lekarskie” 1935, nr 3, s. 233-234.

${ }_{96}$ IX Międzynarodowy Kongres Penitencjarny w Londynie..., s. 3-4.

${ }^{97}$ W. Sokalski IX Międzynarodowy Kongres Penitencjarny. Londyn ..., s. 2.

${ }^{98}$ IX Międzynarodowy Kongres Penitencjarny w Londynie..., s. 4. 
pieczne", stwierdzono, że byłoby pożądanym, aby każdy dorosły człowiek który ujawnił się z niebezpiecznymi skłonnościami był na mocy decyzji sądu umieszczany w „zakładzie lub kolonii, nie mającej charakteru karnego”, poddany tam stosownej dyscyplinie i przebywał tam aż do czasu zwolnienia warunkowego. W tej ostatniej decyzji przewidziano współudział „komisji rzeczoznawców”99. Zwracano uwagę na konieczność szeroko pojętej opieki nad warunkowo zwolnionymi osobami „nienormalnymi” ${ }^{100}$. Jak relacjonował W. Sokalski, to właśnie w trakcie obrad kongresu londyńskiego do obiegu weszło hasło: ,zbrodniarz zostaje przed więzieniem; do więzienia wchodzi człowiek"101. Stwierdził on także, że aby umożliwić lepszą ochronę społeczeństwa przed zbrodnią „domaga się kongres dla przestępców nałogowych (recydywistów), dla przestępców zawodowych i niebezpiecznych, zaprowadzenia systemu zamknięcia prewencyjnego" i oddania tej materii w gestię sądu ${ }^{102}$. Uchwała brzmiała: ,jest rzeczą wskazaną, aby każda osoba dorosła anormalna ujawniająca niebezpieczne skłonności, była z decyzji sądu umieszczona w zakładzie lub kolonii nie mającej charakteru karnego, w której podlegałaby właściwemu regulaminowi i gdzie byłaby pod strażą aż do czasu warunkowego zwolnienia. O zwolnieniu orzekałaby właściwa władza w porozumieniu z komisją znawców”"103. Osoby „nienormalne” miały być ponadto objęte po warunkowym zwolnieniu szeroko zakrojoną opieką postpenitencjarną ${ }^{104}$.

Władzy polskie proponowały Warszawę jako gospodarza kolejnego kongresu w 1930 roku. Ubiegła ją jednak czeska Praga ${ }^{105}$. Obradowano w sierpniu ${ }^{106}$. Warto odnotować, że reagując na postępujące poszerzanie tematyki poruszanej na kongresach, ten zjazd obradował już pod nazwą „Międzynarodowy Kongres Karny i Penitencjarny"107. Podjęto tam już jednoznaczną rezolucję, w której postulowano wprowadzenie systemu progresywnego dla skazanych na długoterminowe kary więzienia ${ }^{108}$. Zalecano ponadto, aby ten model wykonania kary był udziałem większości pozbawionych wolności, przy jednoczesnym akcentowaniu aspektu izolacyjnego i zabezpieczającego względem przestępców uznanych za niewycho-

\footnotetext{
99 Ibidem, s. 6.

${ }^{100}$ Ibidem.

${ }_{101}$ W. Sokalski, IX Międzynarodowy Kongres Penitencjarny. Londyn ..., s. 1.

102 Ibidem, s. 2.

103 Ibidem, s. 3.

104 Ibidem.

${ }_{105}$ IX Międzynarodowy Kongres Penitencjarny w Londynie (na podstawie relacji i materiatów udostepnionych przez Franciszka Głowackiego, dyrektora Departamentu Karnego Ministerstwa Sprawiedliwości), „Przegląd Więziennictwa Polskiego” 1925, nr 5, s. 2.

106 Z. Myśliwski, X Międzynarodowy Kongres Prawa Karnego i Penitencjarnego w Pradze, „Sąd i Obrona” 1930, nr 12, s. 19.

107 E. Holländer, X Międzynarodowy Kongres Karny i Penitencjarny w Pradze....

108 J. Górny, Problematyka penitencjarna ..., s. 12-13.
} 
walnych ${ }^{109}$. Sformułowano jednak także postulat włączenia do składów orzekających takich specjalistów jak lekarzy, pedagogów czy pracowników socjalnych, a ponadto kształcenia sędziów z podstaw pedagogiki i psychologii ${ }^{110}$. Informacje na temat przygotowań do tego kongresu otrzymujemy dzięki relacji E. Neymarka. Pomimo tak wyraźnie zarysowanego odwoływania się do pedagogiki i nauk społecznych, stosowanie środków zabezpieczających miało być jednym z głównych omawianych zagadnień w zakresie ustawodawstwa ${ }^{111}$. Istotnie, w Pradze rozważano systematykę środków ochronnych. Podzielono je na trzy grupy - pozbawiające wolności, niepozbawiające wolności i te o charakterze gospodarczym. $\mathrm{W}$ pierwszej grupie wymieniono:

- internowanie umysłowo chorych i anormalnych, społecznie niebezpiecznych;

- internowanie alkoholików;

- internowanie żebraków i włóczęgów; gowych.

W drugiej grupie jako najskuteczniejszy wymieniono dozór ochronny. Oprócz niego pojawiły się: „kaucja dobrego prowadzenia się”, zakaz wykonywania pewnych zajęć lub zawodów i zakaz uczęszczania do gospód ${ }^{112}$.

Jak relacjonował J. Śliwowski, gdy decydowano o następnym miejscu spotkania, „nie śniło się nikomu, że do władzy w Niemczech dojdzie obecny kierunek polityczny"113.

Na obradującym w rozkwicie nazizmu kongresie berlińskim (19-24 sierpnia 1935 r.) przyjęto modelowe zasady organizacji zakładów przejściowych dla zwolnionych więźniów (homes) i określono cele, jakie powinny one realizować ${ }^{114}$. Rozważano także jakie różnice powinny znamionować wykonanie kary więzienia od środka zabezpieczającego ${ }^{115}$. Stwierdzono tu, że nie jest możliwe precyzyjne określenie w ustawie, jak mają się odróżniać te dwie formy pozbawienia wolności. Jednak obradujący nie mieli wątpliwości, że karę pozbawienia wolności i środki zabezpieczające należy wykonywać w oddzielnych placówkach ${ }^{116}$. Pro-

109 K. Bedyński, Organizacja doskonalenia zawodowego funkcjonariuszy..., s. 268-269.

110 E. Holländer, X Międzynarodowy Kongres Karny i Penitencjarny w Pradze...

111 E. Neymark, X Międzynarodowy Kongres Więziennictwa, „Ruch Prawniczy, Ekonomiczny i Socjologiczny" 1929, R. IX.

112 Z. Myśliwski, X Międzynarodowy Kongres Prawa Karnego i Penitencjarnego w Pradze..., s. $20-21$.

113 XI Kongres Karny i Penitencjarny w Berlinie..., s. 24.

114 S. Glaser, Aktualne zagadnienia na Kongresie Karnym w Berlinie, „Głos Sądownictwa” 1935, nr 10, s. 690, S. Czerwiński, Domy i kolonie przejściowe dla zwolnionych więźniów, „Głos Sądownictwa" 1936, nr 9.

115 S. Glaser, Aktualne zagadnienia na Kongresie Karnym w Berlinie...

116 J. Górny, Rola międzynarodowych kongresów..., s. 83. 
ponowano przy tym, by środek zabezpieczający był pozbawiony elementu dolegliwości, a w konsekwencji by osoby mu poddane miały swobodę w zakresie ubioru, jedzenia, lektur etc. ${ }^{117}$. Jednak atmosfera totalitaryzmu wisiała w powietrzu. Wśród dyskutantów znaleźli się przedstawiciele hitlerowskiego establishmentu, m.in. J. Goebbels ${ }^{118}$. Z. Reich donosił o załamaniu wypracowanej w czasie poprzednich kongresów linii rozwojowej postępowania z więźniami ${ }^{119}$. Kongres został zresztą zbojkotowany przez Howard League for Penal Reform, następczynię prestiżowej Howard Association, która od 1866 roku działała na rzecz reform systemu penitencjarnego ${ }^{120}$. I choć nie pojawił się w Berlinie również żaden z ,poważniejszych przedstawicieli nauki” francuskiej, to jednak kongres zgromadził przedstawicieli 50 państw $^{121}$. Z oczywistych politycznie względów, nie było też nikogo z sowieckiej Rosji ${ }^{122}$. W uchwałach afirmowano kastrację i sterylizację, dopuszczono również podważenie zasady nullum crimen sine lege $e^{123}$. Gospodarze zapewnili sobie przewagę liczebną (w sprawie sterylizacji poparli ich Czesi - delegaci zgłaszający zdanie odrębne zajmowali stanowisko pryncypialne lub zwracali uwagę na to, że są to sprawy zbyt mało jeszcze rozpoznane ${ }^{124}$ ), co miało odzwierciedlenie w przyjmowanych uchwałach ${ }^{125}$. J. Śliwowski zwracał uwagę na, pojawiającą już na poprzednich kongresach, „dyplomatyczną kompromisowość wyników obrad"126 (w tym przypadku dotyczyło to rezolucji mniej ważnych dla gospodarzy). I tak np. koncepcja sterylizacji nie budziłaby większych zastrzeżeń, ale jej wariant przymusowy Niemcy musieli już przeforsować ${ }^{127}$. Tak zorganizowany kongres stał się narzędziem propagandowej afirmacji rozwiązań przyjętych w nazistowskich Niemczech. W dokumentach kongresowych znaleźć można także akcenty wskazujące na odwetową, a mniej poprawczą racjonalizację kary ${ }^{128}$.

Kolejny kongres planowano zorganizować w 1940 roku w Rzymie i w perspektywie tego wydarzenia już w 1935 roku na prezesa organizatora, Międzynarodowej Komisji Karnej i Penitencjarnej, wybrano dyrektora generalnego włoskich

117 S. Glaser, Aktualne zagadnienia na Kongresie Karnym w Berlinie..., s. 692.

118 J. Górny, Międzynarodowe kongresy penitencjarne. Niebezpieczne kompromisy, ,Gazeta Penitencjarna" 1979, nr 5.

119 Z. Reich, XI Kongres Penitencjarny w państwie swastyki, „Głos Prawa” 1935, nr 7-8, s. 466.

${ }^{120}$ Bojkot motywowano brakiem gwarancji zapewnienia uczestnikom wolności w zakresie „wyboru delegatów, słowa w dyskusjach i sprawozdań z kongresu” - ibidem, s. 463.

${ }_{121}$ S. Glaser, Aktualne zagadnienia na Kongresie Karnym w Berlinie..., s. 690.

${ }_{122}$ XI Kongres Karny i Penitencjarny w Berlinie..., s. 25.

${ }_{123}$ Z. Reich XI Kongres Penitencjarny w państwie swastyki...

${ }^{124}$ XI Kongres Karny i Penitencjarny w Berlinie..., s. 25.

${ }^{125}$ S. Glaser Aktualne zagadnienia na Kongresie Karnym w Berlinie..., s. 690.

${ }_{126}$ XI Kongres Karny i Penitencjarny w Berlinie..., s. 25.

127 Ibidem, s. 26.

128 Z. Reich, XI Kongres Penitencjarny w państwie swastyki..., s. 465. 
zakładów wychowawczych i karnych, Giovanniego Novelli ${ }^{129}$. Z oczywistych względów kongres ten się nie odbył.

Pozycja środków zabezpieczających w polityce kryminalnej jest wypadkową dwóch głównych kierunków myśli prawno-karnej: szkoły klasycznej, która przyjmuje jako główne założenie odpowiedzialności karnej istnienie wolnej woli (indeterminizm), zawinienie i pojęcie kary jako odpłaty i różnych nurtów szkoły pozytywistycznej, będącej kontynuacją dawnej szkoły antropologicznej, która przypisywała główną rolę w akcie przestępczym czynnikom biologicznym, zadatkom wrodzonym, a w nurcie socjologicznym także czynnikom środowiskowym i osobowościowym predysponującym do zachowań antysocjalnych. Ta pierwsza perspektywa, zwana prawem karnym „czynu i winy”"130, doprowadziła do wykształcenia się pojęcia niepoczytalności i poczytalności ograniczonej, wiążąc je jednocześnie $\mathrm{z}$ chorobą $\mathrm{i}$ upośledzeniem umysłowym, ta druga natomiast doprowadziła do wprowadzenia na teren prawa karnego niepsychotycznych stanów zmienionej świadomości i utrwalonych postaw antyspołecznych. Tu mają swój rodowód trzy typy środków zabezpieczających. Lecznicze, zbudowane na fundamencie diagnozy psychiatrycznej i zaburzeń rozwojowych, środki lecznicze zbudowane na zaburzeniach osobowości i psychokorekcji i środki eliminacyjne zbudowane na przekonaniu o niepoprawności. Mimo że geneza tych środków jest wyraźnie związana z doktrynami rozwijającymi się w ramach tych kierunków myślenia, w efekcie historycznej ewolucji doszło do specyficznej ich koegzystencji, w rezultacie rozwiązań kompromisowych. Ścieranie się tych nurtów odzwierciedlają rezolucje kongresów i poprzedzające je debaty. Chociaż przedmiot tych rozważań lokuje się w płaszczyźnie historycznej, to jednak zdaje się, że wart jest przypomnienia dorobek tych kongresów, zwłaszcza, że obecne zmiany w prawie karnym wprowadzają do katalogu środków przeciwdziałania przestępczości także środki zabezpieczające.

\title{
DEBATE OVER PREVENTIVE MEASURES IN LIGHT \\ OF THE PROCEEDINGS OF INTERNATIONAL PENITENTIARY CONGRESSES BEFORE WORLD WAR TWO
}

\begin{abstract}
The article presents the debate over the preventive measures in criminal law. This discussion took place on the forum of the international penitentiary congresses between 1846 and 1935. The former date marks the first session in Frankfurt while the latter marks

129 P. Garfinkel, Criminal Law in Liberal and Fascist Italy, Cambridge 2016, s. 469.

${ }^{130}$ W. Wróbel, A. Zoll, Polskie prawo karne. Część ogólna, Kraków 2013, s. 547.
\end{abstract}


the date of the last congress in Rome before the beginning of the Second World War. The penitentiary congresses were an opinion-forming body and their resolutions constituted an important point of reference for legislation. Furthermore, the resolutions provided a crucial guidance for legal practice in countries which aspired to conduct a modern policy in terms of punishments. The paper presents the issue of the preventive measures in contrast with other aspects of the criminal justice system. Moreover, it discusses the wider issue of the quandaries connected with the role of repressive law in the process of solving momentous social problems. Certain organizational aspects were also portrayed. All of them were relevant from the point of view of the selection of problems as well as from the point of view of the practical implementation of the congress resolutions.

\section{DEBAT SUR LES MESURES DE SURETE A LA LUMIERE DES TRAVAUX DES CONGRES PENITENTIAIRES INTERNATIONAUX AVANT LA SECONDE GUERRE MONDIALE}

\section{Resumé}

Le présent article met en lumière le débat sur les mesures de sûreté en matière criminelle qui s'est déroulé dans les congrès pénitentiaires internationaux, à partir de 1846, l'année où le premier congrès s'est tenu à Francfort-sur-le-Main, jusqu'au Congrès de Rome en 1935 - le dernier qui est tenu avant la Seconde Guerre mondiale. Les congrès pénitentiaires ont pris la position du leader d'opinion et leurs résolutions constituaient l'important point de référence pour la législation et la pratique des pays aspirant à mener une politique moderne en matière de sanction. L'article présente la question des mesures de sûreté face à d'autres aspects du système de justice pénale et des dilemmes plus vastes liés au rôle du droit répressif dans la résolution de problèmes socialement importants. Certains aspects organisationnels, importants du point de vue de la sélection des problèmes et de l'application pratique des résolutions des Congrès, ont également été présentés. 